\title{
Open-Source Active Distribution Grid Model with a Large Share of RES- Features, and
} Studies

\author{
Baviskar, Aeishwarya; Hansen, Anca D.; Das, Kaushik
}

Published in:

ICPS 2021: Book of Abstracts

Publication date:

2021

Document Version

Publisher's PDF, also known as Version of record

Link back to DTU Orbit

Citation (APA):

Baviskar, A., Hansen, A. D., \& Das, K. (2021). Open-Source Active Distribution Grid Model with a Large Share of RES- Features, and Studies. In ICPS 2021: Book of Abstracts (pp. 71-71). [179]

\section{General rights}

Copyright and moral rights for the publications made accessible in the public portal are retained by the authors and/or other copyright owners and it is a condition of accessing publications that users recognise and abide by the legal requirements associated with these rights.

- Users may download and print one copy of any publication from the public portal for the purpose of private study or research.

- You may not further distribute the material or use it for any profit-making activity or commercial gain

- You may freely distribute the URL identifying the publication in the public portal 


\title{
Track 4.5 (RIEV04): Renewable Integration \& Electric Vehicle
}

Date: Saturday, Dec 18, 2021

Time: 10:15 AM - 11:30 AM

Paper ID : 179

Open-Source Active Distribution Grid Model with a Large Share of RES- Features, and Studies

\section{Authors:}

Aeishwarya Baviskar

Anca D. Hanseni

Kaushik Das
Technical University of Denmark, Denmark

Technical University of Denmark, Denmark

Technical University of Denmark, Denmark

\begin{abstract}
:
Future distribution grids are likely to shift awayfrom a passive grid consuming power to an active grid with a high share of weather-dependent renewable generation. Distribution grid operations are greatly interlinked between different voltage levels and depend upon the fluctuating load demand. Thus it is imperative to study and analyze multivoltage level distribution grids to understand the challenges and opportunities in a distribution grid with a high share of weatherdependent generation. In this research, an open-source multivoltage level distribution grid model, named the DTU 7k-Bus Active Distribution Grid Model, is presented. The distribution grid model spans across three voltage levels and is modeled on geographical data for network topologies. The generation and load time-series provided with the model are simulated from weather data and derived from measurement data respectively. This work addresses key features of the model and highlights challenges due to the high share of renewables.
\end{abstract}

\section{Paper ID : 284}

Evolution of Integrated Multi-Energy Vector System and Innovation Opportunities

Authors:

Arpit Mantri

MNIT Jaipur, India

Aaquib Firdous

MNIT Jaipur, India

Chandra Prakash Barala

MNIT Jaipur, India

Rohit Bhakar

MNIT Jaipur, India

Parul Mathuria

MNIT Jaipur, India

\begin{abstract}
:
Increasing energy demands and visibly changing climatic conditions have led to various deliberations to look at and mitigate the effects causing this adversity. The Paris agreement received greater attention from major countries aiming to decarbonize energy systems and adopt more Renewable Energy Sources (RES). In this regard, India is already ahead of its ambitious targets in increasing its RES installation capacity. However, given the nature of these RES, it has increased the challenges in power systems and questioned the prime component of energy trilemma which is the security of supply. These challenges need to be addressed to avoid failures; one way is to exploit the various synergies between different energy systems. This can reduce carbon emission and increase the renewable penetration in the energy system and meet the requirements of the changing energy sector. This can be facilitated using Multi Energy Systems (MES). These systems optimally interact with each other at different levels and can increase the overall technical, economic, and environmental performance relative to existing energy systems which are planned and operated independently or separately. This paper discusses the overview of MES concepts, key components,
\end{abstract}

